\title{
Greener Friedel-Crafts Acylation using Microwave-enhanced reactivity of Bismuth Triflate in the Friedel-Crafts Benzoylation of Aromatic Compounds with Benzoic Anhydride
}

\author{
Tran, Phuong Hoang; Nguyen, Hai Truong; Hansen, Poul Erik; Le, Thach Ngoc \\ Published in: \\ Chemistry Select
}

DOI:

$10.1002 /$ slct.201601681

Publication date:

2017

Citation for published version (APA):

Tran, P. H., Nguyen, H. T., Hansen, P. E., \& Le, T. N. (2017). Greener Friedel-Crafts Acylation using Microwaveenhanced reactivity of Bismuth Triflate in the Friedel-Crafts Benzoylation of Aromatic Compounds with Benzoic Anhydride. Chemistry Select, 2(1), 571-575. https://doi.org/10.1002/slct.201601681

\section{General rights}

Copyright and moral rights for the publications made accessible in the public portal are retained by the authors and/or other copyright owners and it is a condition of accessing publications that users recognise and abide by the legal requirements associated with these rights.

- Users may download and print one copy of any publication from the public portal for the purpose of private study or research.

- You may not further distribute the material or use it for any profit-making activity or commercial gain.

- You may freely distribute the URL identifying the publication in the public portal.

Take down policy

If you believe that this document breaches copyright please contact rucforsk@kb.dk providing details, and we will remove access to the work immediately and investigate your claim. 


\title{
Greener Friedel-Crafts Acylation Using Microwave-Enhanced Reactivity of Bismuth Triflate in the Friedel-Crafts Benzoylation of Aromatic Compounds with Benzoic Anhydride
}

\author{
Dr. Phuong Hoang Tran ${ }^{\mathrm{a}}$, Hai Truong Nguyen ${ }^{\mathrm{a}}$, Prof. Poul Erik Hansen ${ }^{\mathrm{b}}$, Prof. Thach Ngoc Le ${ }^{\mathrm{a}}$ \\ ${ }^{a}$ Department of Organic Chemistry, Faculty of Chemistry, University of Science, Vietnam National \\ University-Hochiminh city 70000, Vietnam \\ ${ }^{b}$ Department of Science and Environment, Roskilde University, POB 260, Roskilde DK-4000, \\ Denmark
}

\begin{abstract}
An efficient and facile bismuth trifluoromethanesulfonate-catalyzed benzoylation of aromatic compounds using benzoic anhydride under solvent-free microwave irradiation has been developed. The microwave-assisted Friedel-Crafts benzoylation results in good yields within short reaction times. Bismuth triflate is easily recovered and reused for several times without significant loss of catalytic activity.
\end{abstract}

\section{Introduction}

Friedel-Crafts acylation of aromatic compounds is one of the most frequently used reactions in organic synthesis to form C-C bonds, which is of great important synthesis in the preparation of natural products, active pharmaceutical ingredients, agrochemicals, fine chemicals and fragrances. ${ }^{[1-3]}$ However, traditional Lewis acids such as $\mathrm{AlCl}_{3}, \mathrm{BF}_{3}, \mathrm{FeCl}_{3}, \mathrm{TiCl}_{4}, \mathrm{SnCl}_{2}$, etc. require strictly anhydrous conditions, volatile organic solvents, and stoichiometric amounts, which are not reusable after aqueous work-up and generate corrosive acid waste. ${ }^{[2]}$ The traditional reaction is extremely sensitive to water because most of these Lewis acids immediately react with water and lose their reactivity. Therefore the reactions must be carried out under an inert atmosphere. ${ }^{[4]}$ Consequently, the invention, design and application of a safe and environmentally agreeable process for the Friedel-Crafts reactions are very important. ${ }^{[5-7]}$

Bismuth triflate is an efficient and green catalyst for the Friedel-Crafts acylation. Bismuth triflate is a strong Lewis acid, high tolerance toward water and a recyclable catalyst. ${ }^{[8-10]}$ Under conventional heating, bismuth triflate catalyzes Friedel-Crafts 
acylation of aromatic compounds. However, many of these methods involve acid chlorides, additive reagents, volatile organic solvents, low yields and long reaction times. ${ }^{[11-17]}$

Microwave heating has been shown to dramatically reduce reaction times, increase the yield and the isomer selectivity. ${ }^{[18-21]}$ Many organic reactions proceed much faster with higher yields under solvent-free microwave irradiation compared to conventional heating. ${ }^{[22-26]}$ In this work, we aimed at developing a rapid and efficient method for Friedel-Crafts benzoylation of aromatic compounds using benzoic anhydride as the benzoylating reagent under solvent-free microwave irradiation. The improved protocol is interesting for the design of 'greener' Friedel-Crafts benzoylation.

\section{Results and discussion}

The benzoylation of anisole is chosen as the model reaction and bismuth triflate is used as catalyst. After optimizing the reaction condition, a typical procedure for the Friedel-Crafts benzoylation is: benzoic anhydride $(2 \mathrm{mmol})$ as the reactants for the benzoylation of anisole $(1 \mathrm{mmol})$ and $10 \mathrm{~mol} \%$ of $\mathrm{Bi}(\mathrm{OTf})_{3}$ as the catalyst under microwave irradiation (Scheme 1). The reaction is carried out under microwave irradiation for high performance, good conversion, good selectivity and short reaction time in the absence of an organic solvent.

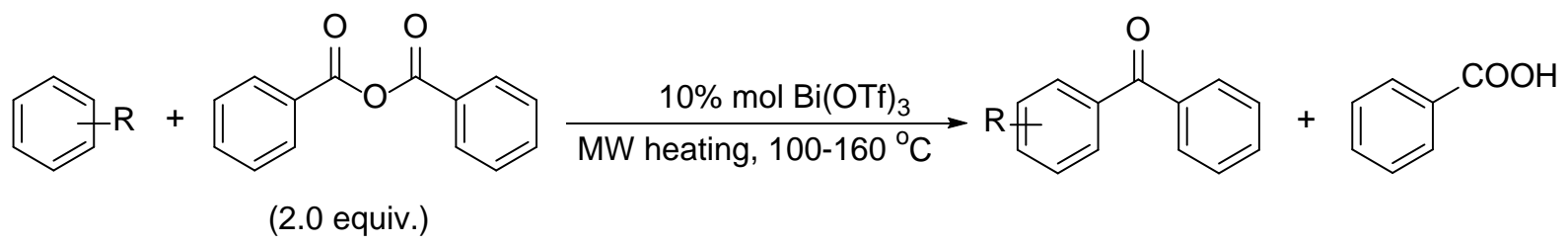

Scheme 1. Bi(OTf $)_{3}$ catalyzed Friedel-Crafts acylation of aromatic compounds under microwave irradiation

The optimized condition was then applied for the Friedel-Crafts benzoylation of various aromatic compounds under microwave irradiation (Table 1). It should be noted that benzoic anhydride is less reactive than acid chlorides because $\mathrm{C}_{6} \mathrm{H}_{5} \mathrm{COO}^{-}$ 
is not good leaving group. It is worth mentioning that as compared to microwave irradiation, conventional heating often results in good yields in a short time in the Friedel-Crafts benzoylation of aromatic compounds with benzoic anhydride as benzoylating reagent. ${ }^{[11]}$

Table 1. Benzoylation of various aromatic compounds catalyzed by bismuth trifluoromethanesulfonate under microwave irradiation.

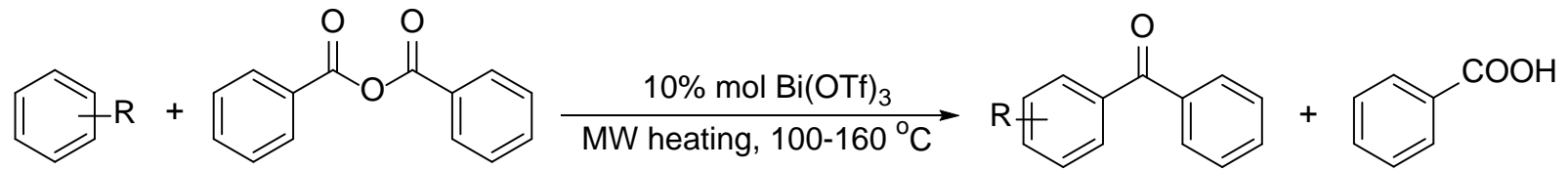

(2.0 equiv.)

$\begin{array}{cccccc}\text { Entry } & \begin{array}{c}\text { Temperature } \\ \left({ }^{\circ} \mathrm{C}\right)\end{array} & \begin{array}{c}\text { Time } \\ (\mathrm{min})\end{array} & 110 & 30 & \begin{array}{c}\text { Yield } \\ (\%)\end{array} \\ \text { Ratio }^{[\mathrm{b}]}\end{array}$


9<smiles>Cc1cccc(C)c1</smiles>

10<smiles>Cc1ccc(Br)cc1</smiles>

140<smiles>CCCc1ccccc1</smiles>

12<smiles>CC(C)c1ccccc1</smiles>

13<smiles>CCCc1ccc(C)cc1</smiles>

14<smiles>CSc1ccccc1</smiles>

15<smiles>c1ccccc1</smiles>

16<smiles>c1ccc2ccccc2c1</smiles>

17<smiles>c1ccc(-c2ccccc2)cc1</smiles>

18<smiles>c1ccc2c(c1)Cc1ccccc1-2</smiles>

19<smiles>c1ccc2cc3ccccc3cc2c1</smiles>

20<smiles>c1ccc2[nH]ccc2c1</smiles>

21

110

110

110

100

160

100
15<smiles>Cc1ccc(C(=O)c2ccccc2)c(C)c1</smiles>

82 6/94

40<smiles>Cc1ccc(Br)cc1C(=O)c1ccccc1</smiles>

20

20<smiles>CCCc1cccc(C(=O)c2ccccc2)c1</smiles>

87 17/0/83

30<smiles>CCCc1ccc(C(=O)c2ccccc2)cc1</smiles><smiles>CC(C)c1ccc([N+](=O)[O-])cc1C(=O)c1ccccc1</smiles>

30<smiles>CSc1ccc(C(=O)c2ccccc2)cc1</smiles>

88 100

40<smiles>O=C(c1ccccc1)c1ccccc1</smiles>

20<smiles>O=C(c1ccccc1)c1ccc2ccccc2c1</smiles>

20<smiles>O=C(c1ccccc1)c1ccc(-c2ccccc2)cc1</smiles>

80 100

20<smiles>O=C(c1ccccc1)c1ccc2c(c1)Cc1ccccc1-2</smiles>

90 100<smiles>O=C(c1ccccc1)c1c2ccccc2cc2ccccc12</smiles>

15<smiles>O=C(Cc1ccccc1)c1cc2ccccc2[nH]1</smiles>

15<smiles>Cc1ccc2[nH]c(-c3ccccc3)cc2c1</smiles> 
Benzoylation of arenes containing alkoxy substituents with benzoic anhydride catalyzed by bismuth triflate under solvent-free microwave irradiation gave products in excellent yields in a short time (Table 1, entries 1-5). The slightly decreased yields in 1,3-dimethoxybenzene and 1,4-dimethoxybenzene can be explained by steric effect due to the electrophile attacking in ortho-position with methoxy substituent (Table 1, entries 4-5). Alkylbenzenes were benzoylated in good yields using high temperature and a long time reaction (Table 1, entries 6-13). The benzoylation of thioanisole was done in $88 \%$ yield, with $100 \%$ selectivity in $p$ position. The non-substituted arenes such as benzene, naphthalene, anthracene, biphenyl and fluorene were also reactive yielding primarily $p$-substituted products (Table 1, entries 15-19). 3-Benzoylindoles are considered to be interesting precursors for many organic transformations and regioselectivity in the 3-benzoylation of indoles is a challenging subject in organic synthesis. ${ }^{[4-5,27-30]}$ Under current method, the benzoylation of indole and 5-methyl indole afforded in high yield, with over $90 \%$ of 3-benzoyindoles (Table 1, entries 20-21).

$\mathrm{Bi}(\mathrm{OTf})_{3}$-catalyzed Friedel-Crafts benzoylation of aromatic compounds employing benzoic anhydride has also been investigated under conventional heating (Table 2). The benzoylation of some alkylbenzenes was conducted to compare with microwave irradiation. The desired products were generally obtained in lower yields despite the fact that the reaction times were prolonged up to six hours (Table 2, entries 1-4).

Table 2. Benzoylation of aromatic compounds catalyzed by bismuth trifluoromethanesulfonate under conventional heating.

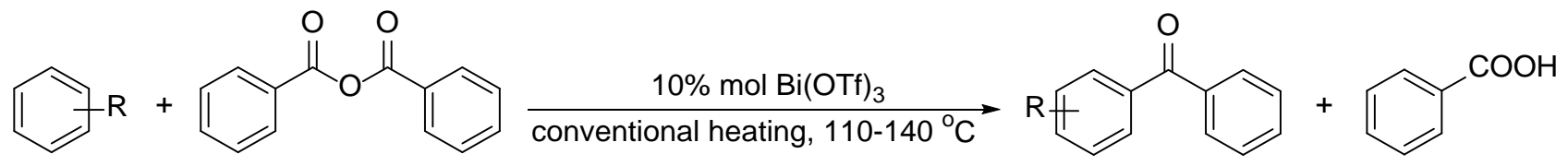

(2.0 equiv.)

\begin{tabular}{lcccccc}
\hline Entry & Arene & $\begin{array}{c}\text { Temperature } \\
\left({ }^{\circ} \mathrm{C}\right)\end{array}$ & $\begin{array}{c}\text { Time } \\
(\mathrm{h})\end{array}$ & Product & $\begin{array}{c}\text { Yield } \\
(\%)\end{array}$ & $\begin{array}{c}\text { Isomer } \\
\text { Ratio }^{[\mathrm{b}]}\end{array}$ \\
\hline 1 & 120 & 6 & & &
\end{tabular}


3

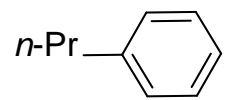

4

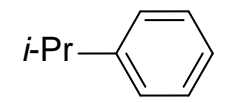

110

110
6<smiles>CCCc1ccc(C(=O)c2ccccc2)cc1</smiles>

6

${ }^{[a]}$ Isolated yield. ${ }^{[b]}$ The isomer ratio is given in the order $\mathrm{o} / \mathrm{m} / \mathrm{p}$ and measured by GC.

The recycling of catalyst has been an important requirement in decreasing environmental pollution and reducing the cost in the industrial process. ${ }^{[31-33]}$ There is some debate about the nature of active species such as a low-concentration of triflic acid, which is formed in the hydrolysis of bismuth triflate. ${ }^{[34]}$ However, Lambert and coworkers reported that $\mathrm{Bi}(\mathrm{OTf})_{3}$ in the presence of substrates indicate that Lewis

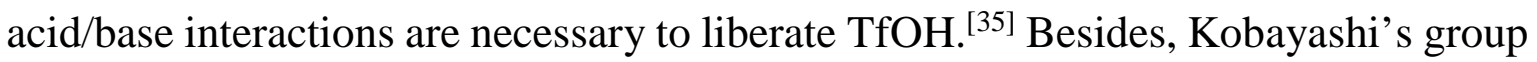
and Desmurs' group reported that acylating reagent is proposed to be acyl triflate, which reacts with aromatic compounds to afford the corresponding products accompanied by regeneration of $\mathrm{TfOH}$, and finally $\mathrm{TfOH}$ reacts with $\mathrm{BiCl}_{3}$ to regenerate $\mathrm{Bi}(\mathrm{OTf})_{3} \cdot{ }^{[8,12,36]}$ Consequently, bismuth triflate could be recovered and reused after aqueous work-up. ${ }^{[10,31,37]}$ In this method, the recovery of bismuth triflate ranges from 93-96\% yields. The catalytic activity was examined by benzoylation of anisole at $110{ }^{\circ} \mathrm{C}$ for $30 \mathrm{~min}$. The results are presented in Scheme 2. Bismuth triflate was recovered and reused up to 5 times with only slightly decreased catalytic activity.

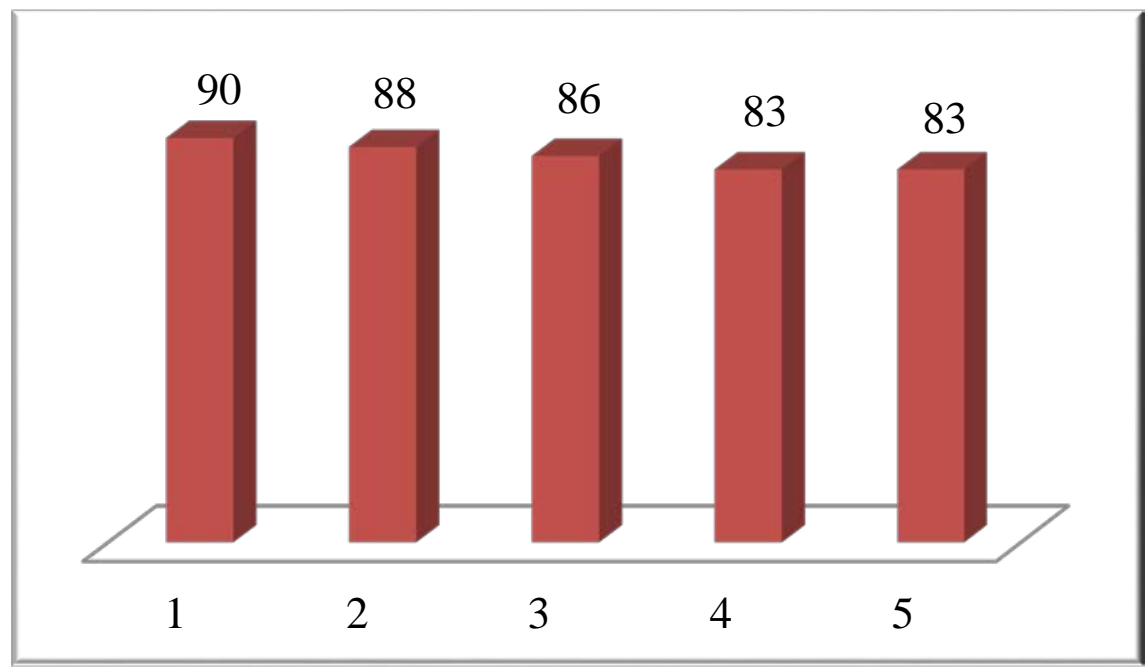

Scheme 2. Recycling of bismuth triflate 


\section{Conclusions}

In summary, using microwave irradiation led to increase in the yields of FriedelCrafts benzoylation of aromatic compounds using benzoic acid anhydride as the acylating agent. Under microwave irradiation, bismuth triflate was found to be a green and efficient catalyst. Besides, microwave irradiation gave higher yields in shorter reaction times than conventional heating. Moreover, bismuth triflate could be recycled up to 5 times without significant loss of catalytic activity.

\section{Supporting Information}

Details materials and methods, characterization data and copies of ${ }^{1} \mathrm{H}$ NMR and ${ }^{13} \mathrm{C}$ NMR spectra are available in the supporting information.

\section{Acknowledgments}

This research is funded by Vietnam National University-Ho Chi Minh City (VNUHCM) under grant number C2016-18-21.

Keywords: Bismuth trifluoromethanesulfonate, Friedel-Crafts acylation, Green process, Microwave irradiation.

\section{References}

[1] G. Sartori, R. Maggi, Advances in Friedel-Crafts acylation reactions: Catalytic and green processes, Taylor \& Francis, Boca Raton, 2010.

[2] S. Jiang, J. Yan, F. Habimana, S. Ji, Catal. Today 2016, 264, 83-90.

[3] P. H. Tran, V. H. Huynh, P. E. Hansen, D.-K. N. Chau, T. N. Le, Asian J. Org. Chem. 2015, 4, 482-486.

[4] S. K. Guchhait, M. Kashyap, H. Kamble, J. Org. Chem. 2011, 76, 4753-4758.

[5] Q. Xing, P. Li, H. Lv, R. Lang, C. Xia, F. Li, Chem. Commun. 2014, 50, 12181-12184.

[6] T. J. Williams, M. F. Greaney, Org. Lett. 2014, 16, 4024-4027.

[7] P. H. Tran, P. E. Hansen, H. M. Hoang, D.-K. N. Chau, T. N. Le, Tetrahedron Lett. 2015, 56, 2187-2192.

[8] S. Kobayashi, M. Sugiura, H. Kitagawa, W. W.-L. Lam, Chem. Rev. 2002, 102, 2227-2302.

[9] T. Ollevier, Org. Biomol. Chem. 2013, 11, 2740-2755.

[10] H. Gaspard-Iloughmane, C. Le Roux, Eur. J. Org. Chem. 2004, 2004, $2517-$ 2532. 
[11] J. R. Desmurs, Tetrahedron Lett. 1997, 38, 8871-8874.

[12] S. Répichet, C. L. Roux, J. Dubac, J.-R. Desmurs, Eur. J. Org. Chem. 1998, 2743-2746.

[13] C. L. Roux, J. Dubac, Synlett 2002, 181-200.

[14] Y. Matsushita, K. Sugamoto, T. Matsui, Tetrahedron Lett. 2004, 45, 47234727.

[15] S. Mazières, C. Le Roux, M. Peyronneau, H. Gornitzka, N. Roques, Eur. J. Inorg. Chem. 2004, 2823-2826.

[16] J. Mahoney, K. Turnbull, M. Cubberley, Synth. Commun. 2012, 42, 32203229.

[17] P. H. Tran, P. E. Hansen, T. T. Pham, V. T. Huynh, V. H. Huynh, T. D. Thi Tran, T. V. Huynh, T. N. Le, Synth. Commun. 2014, 44, 2921-2929.

[18] P. Lidstrom, J. Tierney, B. Wathey, J. Westman, Tetrahedron 2001, 57, 92259283.

[19] D. Adam, Nature 2003, 421, 571-572.

[20] M. Damm, G. Rechberger, M. Kollroser, C. O. Kappe, J. Chromatogr. A 2010, 1217, 167-170.

[21] D. Z. Mijin, M. Baghbanzadeh, C. Reidlinger, C. Oliver Kappe, Dyes Pigm. 2010, 85, 73-78.

[22] M. S. Kumar, K. C. Rajanna, P. Venkanna, M. Venkateswarlu, Tetrahedron Lett. 2014, 55, 1756-1759.

[23] A. Loupy, Microwaves in Organic Synthesis, Wiley-VCH, Weinheim, 2006.

[24] W. Chen, M. Baghbanzadeh, C. O. Kappe, Tetrahedron Lett. 2011, 52, 16771679.

[25] G. G. de la Cruz, K. Groschner, C. Oliver Kappe, T. N. Glasnov, Tetrahedron Lett. 2012, 53, 3731-3734.

[26] T. Ollevier, Z. Li, Eur. J. Org. Chem. 2007, 2007, 5665-5668.

[27] R. Y. Tang, X. K. Guo, J. N. Xiang, J. H. Li, J. Org. Chem. 2013, 78, 1116311171.

[28] L. Yu, P. Li, L. Wang, Chem. Commun. 2013, 49, 2368-2370.

[29] P. Zhang, T. Xiao, S. Xiong, X. Dong, L. Zhou, Org. Lett. 2014, 16, 32643267.

[30] P. H. Tran, H. N. Tran, P. E. Hansen, M. H. N. Do, T. N. Le, Molecules 2015, 20, 19605-19619.

[31] S. Répichet, A. Zwick, L. Vendier, C. Le Roux, J. Dubac, Tetrahedron Lett. 2002, 43, 993-995.

[32] T. C. Wabnitz, J. Q. Yu, J. B. Spencer, Chem. Eur. J. 2004, 10, 484-493.

[33] S. Kobayashi, C. Ogawa, Chem. Eur. J. 2006, 12, 5954-5960.

[34] P. Ondet, G. Lemière, E. Duñach, Eur. J. Org. Chem. 2016. DOI: $10.1002 /$ ejoc.201600937.

[35] R. F. Lambert, R. J. Hinkle, S. E. Ammann, Y. Lian, J. Liu, S. E. Lewis, R. D. Pike, J. Org. Chem. 2011, 76, 9269-9277.

[36] S. Kobayashi, S. lwamoto, Tetrahedron Lett. 1998, 39, 4697-4700.

[37] S. Luo, L. Zhu, A. Talukdar, G. Zhang, X. Mi, J.-P. Cheng, P. G. Wang, MiniRev. Org. Chem. 2005, 2, 177-202. 